\title{
Effects of boundary layer particle formation on cloud droplet number and changes in cloud albedo from 1850 to 2000
}

\author{
J. Merikanto, D. V. Spracklen, K. J. Pringle, and K. S. Carslaw \\ School of Earth and Environment, University of Leeds, Leeds, UK \\ Received: 21 October 2008 - Published in Atmos. Chem. Phys. Discuss.: 26 February 2009 \\ Revised: 13 November 2009 - Accepted: 18 January 2010 - Published: 25 January 2010
}

\begin{abstract}
We use a global aerosol microphysics model to estimate the effect of particle formation through activation nucleation in the boundary layer (BL) on cloud droplet number concentration (CDNC) on global and regional scales. The calculations are carried out for years 1850 and 2000 using historical emissions inventories for primary particles and aerosol precursor gases. Predicted CDNC in 2000 are in good agreement with in-situ observations when activation nucleation is included. We find that BL particle formation increases global annual mean CDNC by approximately the same relative amount in both years $(16.0 \%$ in 1850 and $13.5 \%$ in 2000). As a result, global mean changes in cloud albedo are similar with and without BL particle formation. However, there are substantial regional effects of up to 50\% enhancement or suppression of the 1850-2000 albedo change. Over most modern-day polluted northern hemisphere regions, including BL particle formation scheme suppresses the 1850-2000 increase in CDNC and cloud albedo because BL particle formation is already large in 1850 . Over the Arctic the albedo change is suppressed by $23 \%$ in the annual mean and by $43 \%$ in summer when BL particle formation is taken into account. The albedo change of the persistent stratocumulus cloud deck west of Chile is enhanced by $49 \%$.
\end{abstract}

\section{Introduction}

Cloud droplet number concentration (CDNC) is controlled by the concentration of aerosol particles large enough to act as cloud condensation nuclei (CCN) (Lohmann and Feichter,

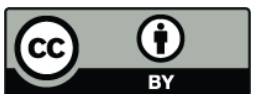

Correspondence to: J. Merikanto

(j.merikanto@leeds.ac.uk)
2005; Dusek et al., 2006). The CDNC depends on the concentration, size distribution and chemical properties of $\mathrm{CCN}$ and on the updraft velocity defining the maximum supersaturation in a cloud parcel (Nenes and Seinfeld, 2003). Higher CDNC leads to an enhanced cloud albedo (Twomey, 1991). This effect is known as the first indirect effect, and its magnitude is one of the most poorly quantified factors in assessing human impacts on climate (IPCC, 2007). Estimates of the aerosol indirect effect obtained from different global climate models (GCMs) vary from $-0.3 \mathrm{Wm}^{-2}$ to $-1.8 \mathrm{Wm}^{-2}$, and the main cause of the spread in results is the difference in predicted aerosol concentrations between different models given a fixed set of sources (Penner et al., 2006).

Observations from several locations around the world suggest that formation of new aerosol particles by nucleation is a frequent phenomenon (Kulmala et al., 2004a). These particles can be first detected in the 3-10 nm diameter range, and their subsequent growth to CCN sizes can be followed. Locally, particle formation has been observed to contribute significantly to CCN (Lihavainen et al., 2005; Kerminen et al., 2005; Laaksonen et al., 2005). Although the fundamental formation mechanism of secondary particles is not well understood, extensive observations in the atmospheric boundary layer (BL) show that the rate of new particle formation is proportional to the sulfuric acid concentration to power 1 (activation nucleation) or 2 (kinetic nucleation) (Weber et al., 1995, 1997; Sihto et al., 2006; Riipinen et al., 2007; Kuang et al., 2008). Measurements also indicate that the main growth mechanics of the newly formed particles is the condensation of secondary organics together with sulfuric acid (O'Dowd et al., 2002). A different mechanism appears to occur above the BL, which is often represented in models as binary homogeneous nucleation of sulfuric acid-water particles (Kulmala et al., 1998; Spracklen et al., 2005a,b; Adams and Seinfeld, 2002).

Published by Copernicus Publications on behalf of the European Geosciences Union. 
$\mathrm{CDNC}$ is controlled by the number of $\mathrm{CCN}$-sized particles that originate from emissions of primary particles or from atmospheric particle formation. In a previous study we used a global aerosol microphysics model to demonstrate that particle formation through activation nucleation in the BL increases the global mean $\mathrm{CCN}(0.2 \%$ supersaturation) concentrations by $3-20 \%$ and CCN (1\%) by $5-50 \%$ (Spracklen et al., 2008). The uncertainties in these values are related to uncertainties in particle formation and growth rates. Thus BL particle formation is an important, though still quite uncertain, source of $\mathrm{CCN}$ in the present atmosphere. But the important question for climate is whether the contribution of $\mathrm{BL}$ particle formation to $\mathrm{CCN}$ has changed over the industrial period, which would affect the calculated aerosol indirect forcing. There are reasons to suspect that it might have changed. In Spracklen et al. (2006) we showed that changes in primary emissions could lead to non-linear changes in particle number: primary emissions are a source of particles but also a sink for nuclei. We showed that the total number of particles initially goes down as primary emissions are reduced, but as they are reduced further particle number goes up again because BL particle formation becomes enhanced. Gaydos et al. (2005) and Jung et al. (2006) also showed a non-linear response of nucleation to $\mathrm{SO}_{2}$ emissions in a box model. But the impact of long-term changes in nucleating vapours and primary particles is likely to be complex and regionally variable because of the non-linear response of nucleation to production and loss processes.

The importance of activation nucleation in the BL has been recently studied also with other global models. Makkonen et al. (2009) used ECHAM5-HAM to show that activation nucleation is likely to enhance global present day CDNC significantly, but also noted that the uncertainties in the mechanism lead to large uncertainties in the obtained CDNC. Wang and Penner (2009) studied the effect of activation nucleation on present day and pre-industrial $\mathrm{CCN}$ and on the first indirect effect. They found that this mechanism increased present day global boundary layer $\mathrm{CCN}$ by $31.4 \%$ when no primary emitted sulfate was included and $5.3 \%$ when primary sulfate was included. Overall, activation nucleation reduced the anthropogenic fraction of $\mathrm{CCN}$ and decreased the first aerosol indirect effect. In another recent model study, Pierce and Adams (2009) also obtained a 5\% increase in global CCN due to activation nucleation, but also pointed out that the sensitivity of CCN to different nucleation scenarios depended on the selected primary emission and secondary organic aerosol schemes.

Here, we extend our model simulations of present day $\mathrm{CCN}$ to quantify the effect of BL particle formation on CDNC and cloud albedo under pre-industrial (1850) and present-day (2000) conditions. We use a mid-range estimate for the BL particle formation rate leading to a $10-20 \%$ increase in global present-day CCN. Our aim is not to calculate a new value for the indirect forcing, but to demonstrate that while work is in progress to improve the representation of aerosol in GCMs, BL particle formation should be considered due to its sizable contribution to CDNC and to estimates of the cloud albedo change.

\section{Model description}

We use the global aerosol microphysics model GLOMAP, which is an extension of the offline 3-D chemical transport model TOMCAT (Chipperfield, 2006). Full details of the model microphysics scheme are described in Spracklen et al. (2005a). GLOMAP treats two externally mixed aerosol distributions described by a two-moment sectional scheme with 20 sections spanning $3 \mathrm{~nm}$ to $25 \mu \mathrm{m}$ dry diameter. One of the distributions is partly hydrophyllic including sulfate, sea-salt, black carbon (BC) and organic carbon (OC). The other distribution representing freshly emitted primary carbonaceous particles contains $\mathrm{BC}$ and $\mathrm{OC}$ and is assumed to be hydrophobic. The hydrophobic $\mathrm{OC}$ and $\mathrm{BC}$ particles are transferred to the hydrophyllic distribution through coagulation and condensation of soluble gas-phase species. These species include gaseous $\mathrm{H}_{2} \mathrm{SO}_{4}$ and the first-stage oxidation products of monoterpenes (Guenther et al., 1995), which form hydrophilic secondary organic aerosol material with an assumed yield of $13 \%$ (Spracklen et al., 2006). The model has a horizontal resolution of $\sim 2.8^{\circ}$ by $\sim 2.8^{\circ}$ with 31 vertical levels between the surface and $10 \mathrm{hPa}$ and is forced by analyses from the European Centre for Medium-Range Weather Forecasts for the year 2000. The same meteorology and oxidants are used both for 1850 and 2000 runs.

New particle formation is modelled with the cluster activation theory (Kulmala et al., 2006). According to this scheme, nucleation rate of $1 \mathrm{~nm}$ clusters $J_{1}\left[\mathrm{~cm}^{-3} \mathrm{~s}^{-1}\right]$ is given by

$J_{1}=A\left[\mathrm{H}_{2} \mathrm{SO}_{4}\right]$,

where $J_{1}$ is the, $\left[\mathrm{H}_{2} \mathrm{SO}_{4}\right]$ is the gas phase sulfuric acid concentration in $\mathrm{cm}^{-3}$ and $A$ is the activation coefficient. Here we have used $A=2 \times 10^{-6} \mathrm{~s}^{-1}$, which is based on empirical calculations (Sihto et al., 2006) and on our previous comparisons with ground level observations (Spracklen et al., 2006, 2008). Calculated A-factors for observed nucleation events vary temporally and regionally between $A=$ $10^{-8}-10^{-4} \mathrm{~s}^{-1}$ (Riipinen et al., 2007). However, reasons for the variations in A-factor are not known.

The effective formation rate of $3 \mathrm{~nm}$ particles added to the first size bin is obtained with the parameterization of Kerminen and Kulmala (2002), expressed as

$J_{3}=J_{1} \exp \left(-0.153 \frac{\mathrm{CS}^{\prime}}{\mathrm{GR}}\right)$,

where $\mathrm{CS}^{\prime}$ is the reduced condensation sink and $\mathrm{GR}\left(\mathrm{nm} \mathrm{h}^{-1}\right)$ is the cluster growth rate, assumed to be constant between $1 \mathrm{~nm}$ and $3 \mathrm{~nm}$ and given by $0.73 \cdot 10^{-7}\left[\mathrm{H}_{2} \mathrm{SO}_{4}\right]$. In reality, the growth rate may depend on the concentration of secondary organics and on the particle size (Kulmala et al., 
2004b; Hirsikko et al., 2005). However, a large body of experimental evidence supports the idea that particle formation rates depend mainly on the interplay between the sulfuric acid concentration and condensation sink, as in the above parameterization.

The above particle formation mechanism is confined to the $\mathrm{BL}$ in our model runs. Aircraft observations suggest that the total particle concentration has a minimum just above the BL (Schroder et al., 2002). The concentrations increase again in the free and upper troposphere, where homogeneous binary $\mathrm{H}_{2} \mathrm{O}-\mathrm{H}_{2} \mathrm{SO}_{4}$ or ternary $\mathrm{H}_{2} \mathrm{O}-\mathrm{H}_{2} \mathrm{SO}_{4}-\mathrm{NH}_{3}$ particle formation mechanisms are the most likely sources of new particles (see e.g. Kulmala et al. (1998); Merikanto et al. (2007)). Above the boundary layer we use the parameterized $\mathrm{H}_{2} \mathrm{O}-\mathrm{H}_{2} \mathrm{SO}_{4}$ particle formation rates of Kulmala et al. (1998), which we have previously shown to reproduce the observed particle number concentrations in the upper troposphere (Spracklen et al., 2005a). However, in this study we focus only on the effects of BL particle formation.

The cloud drop number concentration (CDNC) is calculated from the time-averaged hydrophyllic particle distribution using the iterative scheme of Nenes and Seinfeld (2003) and Fountoukis and Nenes (2005). The application of this scheme in GLOMAP is described in Pringle et al (2009). The schemes take into account the fraction of soluble material in the particles and the number of ions released into the solution, and are capable of predicting the observed CDNC with good accuracy (Meskhidze et al., 2005). The calculations are carried out for every grid box regardless of the presence of clouds at $300-1000 \mathrm{~m}$ above ground level. The CDNC are calculated as a diagnostic and are not fed back into the aerosol microphysics. Cloud droplet activation in clouds is modeled using a constant activation dry diameter of $50 \mathrm{~nm}$. In an earlier GLOMAP study the $50 \mathrm{~nm}$ activation diameter was found to correspond to a minimum updraft velocity of approximately $0.4 \mathrm{~m} / \mathrm{s}$ in the Nenes and Seinfeld (2003) parameterization both in polluted and clean conditions (Fig. 8 in Korhonen et al., 2008).

The changes in aerosol, and hence in cloud drop number, are quantified using emissions for 1850 and 2000. The anthropogenic sulfur emissions, accounting also for changes in wildfires, are taken from the inventory of Smith et al. (2004). According to this inventory, the global sulfur emissions have increased from 1.4 to $59.4 \mathrm{Tg}(\mathrm{S}) \mathrm{a}^{-1}$ between 1850 and 2000 . We emit $2.5 \%$ of sulfur directly as particulate sulfate with mode diameters of $60 \mathrm{~nm}(50 \%$ of ground level sulfate emissions), $150 \mathrm{~nm}$ ( $50 \%$ of ground level sulfate emissions), $150 \mathrm{~nm}$ (50\% of elevated sulfate emissions) and $1500 \mathrm{~nm}$ (50\% of elevated sulfate emissions). The remaining $97.5 \%$ of athropogenic sulfur is emitted as $\mathrm{SO}_{2}$. The marine dimethylsulfide emissions and sulfur emissions from constantly erupting volcanoes are assumed to be the same for both years, accounting for $17.7 \mathrm{Tg}(\mathrm{S}) \mathrm{a}^{-1}$ and $13.0 \mathrm{Tg}(\mathrm{S}) \mathrm{a}^{-1}$ respectively. We use the inventory of Bond et al. (2007) for energy related emissions of $\mathrm{BC}$ and $\mathrm{OC}$, and further separate
Table 1. Comparison of modelled $2000 \mathrm{CDNC}\left[\mathrm{cm}^{-3}\right]$ to $\mathrm{CDNC}$ observed in in-situ measurement campaigns. Model calculations are carried out with typical updraught velocities $(\bar{w})\left[\mathrm{ms}^{-1}\right]$ observed during the campaigns. Results are shown with (BLPF) and without (no BLPF) boundary layer particle formation.

\begin{tabular}{lcccc}
\hline Location & $\bar{w}$ & no BLPF & BLPF & Observed \\
\hline Beaufort sea (April) & 0.4 & 70 & 86 & $90^{\mathrm{a}}$ \\
Key West (July) & 2.0 & 409 & 631 & $836 \pm 727^{\mathrm{b}}$ \\
Monterey (July) & 0.2 & 274 & 298 & $378 \pm 72^{\mathrm{b}}$ \\
Cleveland (August) & 0.4 & 566 & 763 & $881 \pm 285^{\mathrm{c}}$ \\
\hline
\end{tabular}

${ }^{a}$ Gultepe and Isaac (2002, 2004); ${ }^{b}$ Meskhidze et al. (2005);

${ }^{\mathrm{c}}$ Fountoukis et al. (2007).

these emissions into biofuel and fossil fuel components using the database of Fernandes et al. (2007). Monthly wildfire BC and OC emissions are from Dentener et al. (2006), where the values for 1850 are obtained by taking a population weighted average of 1750 and 2000 emissions. The total global BC particulate emissions are $2.1 \mathrm{Tga}^{-1}$ and $8.0 \mathrm{Tga}^{-1}$ for 1850 and 2000 , respectively, and $20.5 \mathrm{Tga}^{-1}$ and $49.2 \mathrm{Tga}^{-1}$ for OC. The sea-salt emissions are calculated using Gong (2003) and are identical for both years. Emissions of monoterpenes are from Guenther et al. (1995) and are assumed to be identical for both years.

\section{Results}

\subsection{Evaluation of model cloud droplet number}

As a basic check on model-predicted CDNC we have compared our results against in-situ observations from four aircraft measurement campaigns carried out over the Arctic ocean and in US (Gultepe and Isaac, 2002, 2004; Meskhidze et al., 2005; Fountoukis et al., 2007) (Table 1). The updraft velocities $\bar{w}$ during the aircraft measurements have been recorded for each of these campaigns. In our calculations we have used a representative average values of $\bar{w}$ corresponding to in-situ measurements. The CDNC values with particle formation are in reasonably good agreement with observations while the mean CDNC is slightly underestimated. The model without BL particle formation clearly underestimates the mean CDNC in all cases. Given the uncertainties in updraft velocity, particle composition and size distribution these differences cannot be used to demonstrate that the BL particle formation model is correct, but overall the modelobservation agreement gives confidence in predicted CDNC for present-day conditions. 
$\operatorname{CS}(2000) / \operatorname{CS}(1850)$
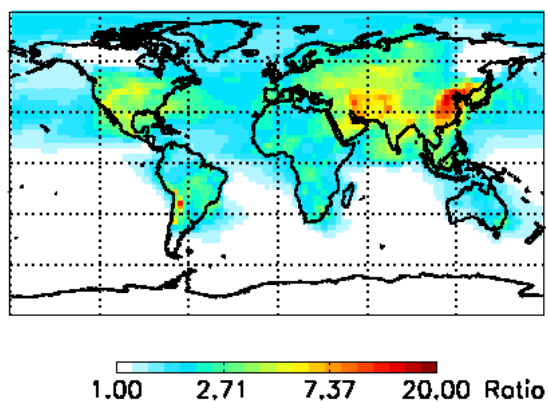

$\mathrm{N}(3-10 \mathrm{~nm})-\mathrm{N}^{\prime}(3-10 \mathrm{~nm})$, yeor 1850

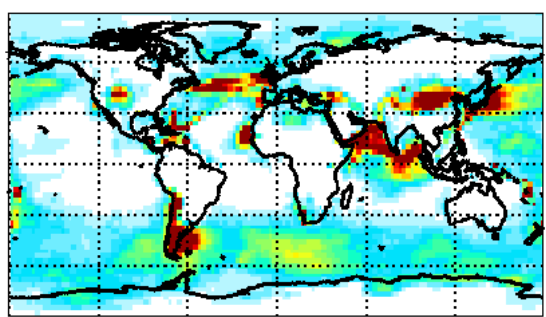

$12505007501000 \mathrm{~cm}^{-3}$
[H2SO4(2000)]/[H2SO4(1850)]

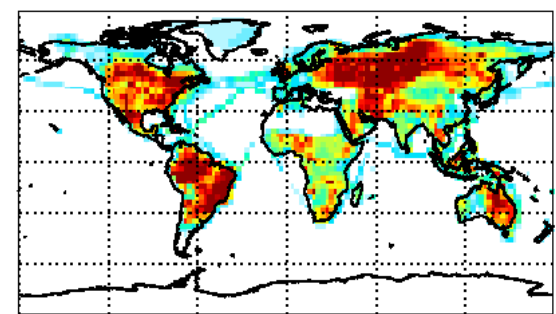

$\begin{array}{llll}1.00 & 2.71 & 7.37 & 20.00\end{array}$

$\mathrm{N}(3-10 \mathrm{~nm})-\mathrm{N}^{\prime}(3-10 \mathrm{~nm})$, yeor 2000

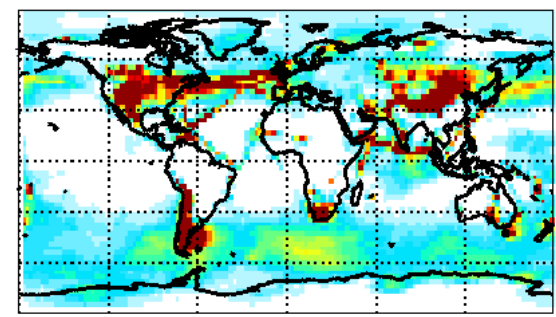

$12505007501000 \mathrm{~cm}^{-3}$

Fig. 1. Upper panels: The ratio of annual mean 2000 and 1850 values for condensation sink (CS) and gas-phase sulfuric acid concentration at 300-1000 m above ground level. Lower panels: The difference in concentrations of $3 \mathrm{~nm}-10 \mathrm{~nm}$ particles with (N) and without (N') boundary layer particle formation in 1850 and 2000 at 300-1000 $\mathrm{m}$ above ground level.

\subsection{Changes in aerosol and condensation sink}

The formation rate of $3 \mathrm{~nm}$ particles depends primarily on the sulfuric acid concentration and the magnitude of the condensation sink. Figure 1 shows the ratio of 1850 and 2000 yearly mean condensation sinks and the ratio of sulfuric acid concentrations, and the concentrations of 3-10 nm particles resulting from BL particle formation. Already in the relatively clean atmosphere in $1850 \mathrm{BL}$ particle formation has produced significant amounts of new particles. Considering that the anthropogenic sulfur emissions in 1850 are only $1.4 \mathrm{Tg}(\mathrm{S}) \mathrm{a}^{-1}$ compared to $\mathrm{Tg}(\mathrm{S}) \mathrm{a}^{-1} \mathrm{TgS} / \mathrm{yr}$ from natural sulfur emissions most of the formation in 1850 must be driven by natural sulfur sources. The gaseous sulfuric acid concentration has increased from 1850 to 2000 mainly over continental regions where anthropogenic emissions have increased from 1850 to 2000 . Over the continents typical changes in condensation sink are smaller in magnitude than the changes in sulfuric acid concentration. Therefore, the average continental $\mathrm{BL}$ particle formation rates are larger in 2000 than in 1850 . On the other hand, in many marine regions especially in the northern hemisphere, the condensation sink has grown due to increased shipping and outflow of aged particles causing the formation rates in these regions to decrease or to stay constant. A smaller proportion of newly formed marine particles is able to grow to large sizes in 2000 than in 1850 because the changes in condensation sink are larger than changes in condensing sulfuric acid as shown in Fig. 1.

\subsection{Changes in cloud droplet number}

Figure 2 shows the predicted CDNC for 1850 and 2000 with activation-type BL particle formation. Here, we have used a typical value of $0.4 \mathrm{~m} / \mathrm{s}$ for the cloud updraft velocity, which approximately corresponds to the constant cloud activation nuclei dry diameter of $50 \mathrm{~nm}$ used in the simulations. Measured updraft velocities in BL clouds vary greatly but range typically between $0.3-0.5 \mathrm{~m} / \mathrm{s}$ (Nenes et al., 2001). The increase in anthropogenic emissions from 1850 to 2000 has clearly had a profound effect on the CDNC. In both 1850 and 2000 particle formation increases CDNC substantially, as shown in the lower panels of Fig. 2. Surprisingly, the globally averaged contribution of particle formation to CDNC has been quite similar in both years regardless of changes in emissions. BL Particle formation increases global mean CDNC by $16.0 \%$ in 1850 and $13.5 \%$ in 2000, indicating that the global relative contribution to CDNC has been quite similar. This is in line with the result of Pierce and Adams (2009), who found that the sensitivity of cloud condensation nuclei to activation particle formation was similar in their pre-industrial and present day simulations. 
CDNC(1850) with BLPF

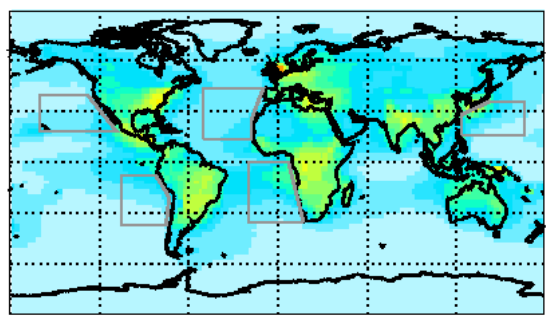

$1200400600800 \mathrm{~cm}^{-3}$ $\operatorname{CDNC}(1850)-\operatorname{CDNC}^{\prime}(1850)$

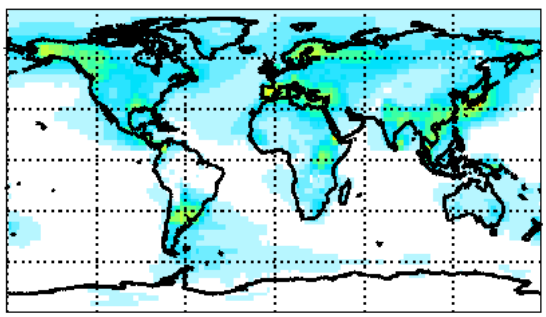

$150100150200 \mathrm{~cm}^{-3}$
CDNC(2000) with BLPF

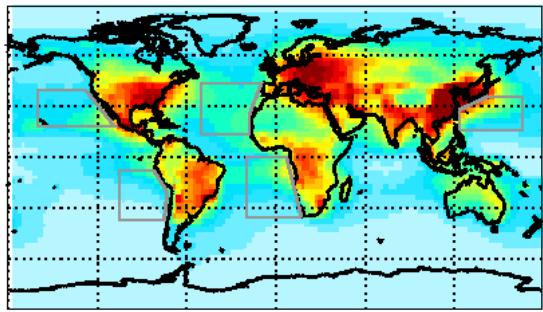

$1200400600800 \mathrm{~cm}^{-3}$ $\operatorname{CONC}(2000)-\operatorname{CDNC}^{\prime}(2000)$

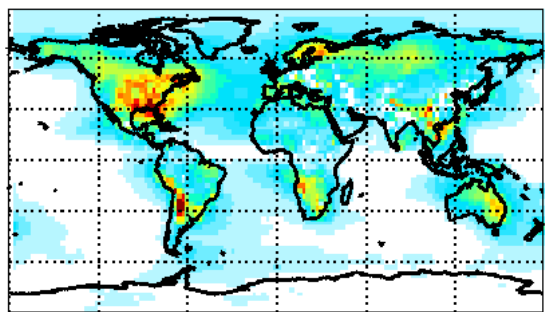

$150100150200 \mathrm{~cm}^{-3}$

Fig. 2. Upper panels: Annual mean cloud droplet number concentration at 300-1000 m above ground level with BL particle formation. Results are shown for 1850 and 2000. Lower panels: The difference in cloud droplet number concentration with and without activation-type BL particle formation in 1850 and 2000. The updraft velocity is taken to be $\bar{w}=0.4 \mathrm{~m} / \mathrm{s}$ in all cases. Grey boxes show marine regions with persistent stratiform cloud formation.

In both years CDNC is higher over continents than marine areas, but the marine-continent contrast is much larger in 2000 than in 1850. Large differences in continental CDNC can also be seen in less industrialized regions, like over the equatorial Africa and South America. These differences are mostly due to increases in particulate emissions from biofuel and forest burning. However, BL particle formation still accounts for a significant proportion of CDNC in these areas regardless that the in-situ particle formation rates are negligible. This can be seen by comparing the lower panels of Fig. 2 to the original locations of BL particle formation shown in the lower panels of Fig. 1. The differences in the patterns in these figures are due to long range transport of particles: the effect of BL particle formation on CDNC spreads to remote regions where particle formation does not take place in-situ.

Changes in CDNC are summarized in Table 2 for several continental regions and marine regions with persistent stratiform cloud formation, indicated in Fig. 2 by gray boxes in the upper two panels. A clear increase in CDNC can be seen in all cases when particle formation is included. The globally averaged fractional changes in CDNC are quite similar in the runs with and without BL particle formation $(66.1 \%$ and $68.7 \%$ respectively, see Table 2). However, there are large regional differences in the relative importance of BL particle formation. Particularly, in many parts of the north- ern hemisphere the relative contribution of BL particle formation in 2000 is less than in 1850. This is particularly the case in modern-day polluted regions. On the other hand, in the southern hemisphere the relative contribution of BL particle formation to CDNC is greater in 2000 than 1850, probably due to assumed increase in $\mathrm{SO}_{2}$ emissions by wildfires in Amazonian, West African and Australian regions. This result could be reversed if global wildfires were more abundant in 1850 than in 2000 as suggested by Marlon et al. (2008), contrary to AEROCOM predictions (Dentener et al., 2006). It appears that already in $1850 \mathrm{BL}$ particle formation made a substantial contribution to Arctic CDNC both through particle transport and in-situ formation. In the Arctic, BL particle formation suppresses the 1850-2000 change in CDNC. Overall, 1850-2000 increase in CDNC with BL particle formation shows a very different pattern than 1850-2000 increase in CDNC if BL particle formation is omitted.

\subsection{Changes in cloud albedo}

The change in cloud albedo $\Delta \mathrm{Rc}$ during the period is related to the relative change in cloud droplet number. If we assume that there have been no significant changes in the cloud liquid water content or cloud height we can write (Twomey, 1991) 
Table 2. Summary of yearly average $\mathrm{CDNC}\left[\mathrm{cm}^{-3}\right]$ and $\Delta \mathrm{Rc}$ obtained from model runs at 300-1000 m above ground level. Primed values indicate results without BLPF. CDNC is calculated with an updraft velocity $\bar{w}=0.4 \mathrm{~m} / \mathrm{s}$. $\Delta \mathrm{Rc}$ is the corresponding change in albedo for an initial albedo of $R c=0.35$ The last column shows the correction from BLPF to albedo change, $\left(\Delta \mathrm{Rc}-\Delta \mathrm{Rc}^{\prime}\right) / \Delta \mathrm{Rc}^{\prime}$. The marine regions refer to west of North America (NAM), west of South America (SAM), west of North Africa (NAF), west of South Africa (SAF), and East of North-East Asia (NEA) (see Fig. 2).

\begin{tabular}{|c|c|c|c|c|c|c|c|}
\hline \multirow[b]{2}{*}{ Region } & \multicolumn{2}{|c|}{1850} & \multicolumn{2}{|c|}{2000} & \multirow[b]{2}{*}{$\Delta \mathrm{Rc}^{\prime} \%$} & \multirow[b]{2}{*}{$\Delta \mathrm{Rc} \%$} & \multirow[b]{2}{*}{$\frac{d \Delta \mathrm{Rc}}{\left|\Delta \mathrm{Rc}^{\prime}\right|} \%$} \\
\hline & $\mathrm{CDNC}^{\prime}$ & $\mathrm{CDNC}$ & $\mathrm{CDNC}^{\prime}$ & CDNC & & & \\
\hline Total Global & 125 & 145 & 211 & 240 & 3.97 & 3.85 & -3.0 \\
\hline Arctic & 54 & 81 & 86 & 116 & 3.60 & 2.72 & -24.3 \\
\hline North temperate zone & 139 & 173 & 325 & 374 & 6.47 & 5.85 & -9.6 \\
\hline Northern tropics & 141 & 161 & 250 & 274 & 4.33 & 4.03 & -6.7 \\
\hline Southern tropics & 167 & 178 & 217 & 243 & 1.97 & 2.35 & 19.4 \\
\hline South temperate zone & 88 & 101 & 104 & 125 & 1.30 & 1.64 & 25.8 \\
\hline Antarctic & 56 & 64 & 56 & 64 & 0.027 & 0.053 & 94.5 \\
\hline Total Marine & 102 & 117 & 155 & 176 & 3.13 & 3.09 & -1.2 \\
\hline NAM & 99 & 114 & 214 & 236 & 5.81 & 5.52 & -5.0 \\
\hline SAM & 107 & 116 & 127 & 149 & 1.30 & 1.94 & 49.2 \\
\hline NAF & 92 & 113 & 199 & 241 & 5.82 & 5.76 & -0.9 \\
\hline SAF & 142 & 151 & 165 & 186 & 1.17 & 1.58 & 34.7 \\
\hline NEA & 127 & 168 & 352 & 389 & 7.77 & 6.34 & -18.4 \\
\hline Total Continental & 186 & 219 & 362 & 413 & 5.04 & 4.81 & -4.7 \\
\hline Europe & 232 & 291 & 562 & 621 & 6.73 & 5.75 & -14.6 \\
\hline Africa & 233 & 263 & 377 & 419 & 3.65 & 3.52 & -3.6 \\
\hline N. America & 170 & 215 & 330 & 419 & 5.05 & 5.05 & 0.1 \\
\hline S. America & 250 & 274 & 408 & 466 & 3.72 & 4.02 & 8.1 \\
\hline N.'Asia & 117 & 152 & 280 & 336 & 6.63 & 6.00 & -9.5 \\
\hline SE Asia & 203 & 245 & 558 & 598 & 7.65 & 6.75 & -11.8 \\
\hline Oceania & 219 & 243 & 287 & 352 & 2.05 & 2.80 & 36.1 \\
\hline
\end{tabular}

$\Delta \mathrm{Rc}=\mathrm{Rc}(1-\mathrm{Rc}) / 3 \ln \left(\frac{\mathrm{CDNC}(2000)}{\mathrm{CDNC}(1850)}\right)$

where Rc is the cloud initial albedo. The difference in cloud albedo change with and without BL particle formation is given by

$$
\begin{aligned}
d \Delta \mathrm{Rc} & =\Delta \mathrm{Rc}-\Delta \mathrm{Rc}^{\prime} \\
& =\mathrm{Rc}(1-\mathrm{Rc}) / 3 \ln \left(\frac{\left(\frac{\mathrm{CDNC}(2000)}{\operatorname{CDNC}(1850)}\right)}{\left(\frac{\operatorname{CDNC}^{\prime}(2000)}{\operatorname{CDNC}^{\prime}(1850)}\right)}\right),
\end{aligned}
$$

where the primed values indicate results without BL particle formation. The logarithmic term in the above equation, the ratio of $\mathrm{CDNC}$ ratios between runs with and without $\mathrm{BL}$ particle formation, shows that BL particle formation has an effect on albedo change only if its relative contribution to $\mathrm{CDNC}$ has changed over time. A schematic representation of the effects of particle formation is shown in Fig. 3. It shows that particle formation can both enhance and suppress the obtained albedo changes. To calculate $\Delta \mathrm{Rc}$ we assume an initial albedo of 0.35 . Although the 1850-2000 changes in albedo are affected by the assumed initial albedo, the as- sumption does not alter the calculated relative impact of BL particle formation.

Figure 4 shows the resulting changes in $\Delta \mathrm{Rc}$ with and without BL particle formation. The figure shows the averaged full year and northern hemisphere summer values. The regional patterns of $\Delta \mathrm{Rc}$ are quite strongly affected by particle formation. For example, during the northern hemisphere summer BL particle formation completely suppresses the albedo change over large parts of the Arctic region. The full year regional changes are summarized in Table 2. The global mean albedo change is predicted to be $3.97 \%$ with BL particle formation and $3.85 \%$ without, so the globally averaged impact of BL particle formation is negligible. However, the negligible effect of BL particle formation on average global albedo change may be coincidental and related to the selected representation of emissions, as discussed in Introduction. Using different but plausible combinations of emissions could lead to both increase or decrease in the average global albedo change due to BL particle formation.

Figure 5 shows the impact of including BL particle formation in the model on the $2000 / 1850 \Delta R c$ for four northern hemisphere seasons. The impact on $\Delta \mathrm{Rc}$ is given by 
$d \Delta \mathrm{Rc} /\left|\Delta \mathrm{Rc}^{\prime}\right|$ and is independent of the initial albedo. We note that results are similar with different updraft velocities, although the regional differences are more pronounced with higher updrafts. This is because the importance of activation BL nucleation on CDNC decreases with smaller updrafts due to increasing cloud droplet activation radius. Clouds that are most susceptible to albedo change may have smaller characteristic updrafts than $0.4 \mathrm{~m} / \mathrm{s}$, but larger impact of BL nucleation on high updraft clouds would partly compensate this.

Blue areas in Fig. 5 indicate regions where the 1850 to 2000 changes in CDNC or $\triangle \mathrm{Rc}$ are reduced by including BL particle formation, and red areas indicate where the changes are increased. It can be seen that BL particle formation has a substantial regional impact on calculated $\Delta$ Rc. In large parts of the globe $d \Delta \mathrm{Rc} /\left|\Delta \mathrm{Rc}^{\prime}\right|$ exceeds $50 \%$. The results show a large north-south contrast: BL particle formation reduces the calculated albedo change in the north and increases it in the south. Results show relatively high seasonal variation, and the largest regional changes are obtained during the northern hemisphere summer. During the summer the positive albedo change in the northern hemisphere is greatly reduced, except in North America where BL particle formation results in a larger positive albedo change. In the south tropics BL particle formation enhances the obtained albedo change during all seasons. The changes in the Antarctic region are not statistically significant since the obtained albedo change is negligible in all cases.

In their recent study Wang and Penner (2009) found that BL particle formation through activation nucleation decreases the first aerosol indirect effect especially over northern hemisphere oceans. Also in our simulations the albedo change is decreased in these regions. Over northern hemisphere land regions Wang and Penner (2009) found a modest decrease in the first indirect effect due to BL particle formation when primary sulfate was included, or a modest increase in the first indirect effect when primary sulfate was not included. According to our results the albedo change is decreased over most northern hemisphere land areas (except spring and summer seasons in Canada and Siberia due to reductions in wildfire emissions since 1850 in these regions). Our results suggest an enhanced albedo change over most of the southern hemisphere, while Wang and Penner (2009) obtained a modest decrease or no change at all in this region depending on the applied primary sulfate scheme.

Our model simulations show that BL particle formation has a regionally variable impact on CDNC and albedo changes between 1850 and 2000. In some regions the increases in albedo are enhanced when BL particle formation is included, while in other regions it is suppressed. The regional differences arise because the relative contribution of BL particle formation to aerosol in 1850 and 2000 has changed (illustration in Fig. 3). In regions where albedo changes are suppressed, BL particle formation had a greater proportional effect on aerosol in 1850 than in 2000, and vice versa in regions where albedo changes are enhanced. A greater pro-
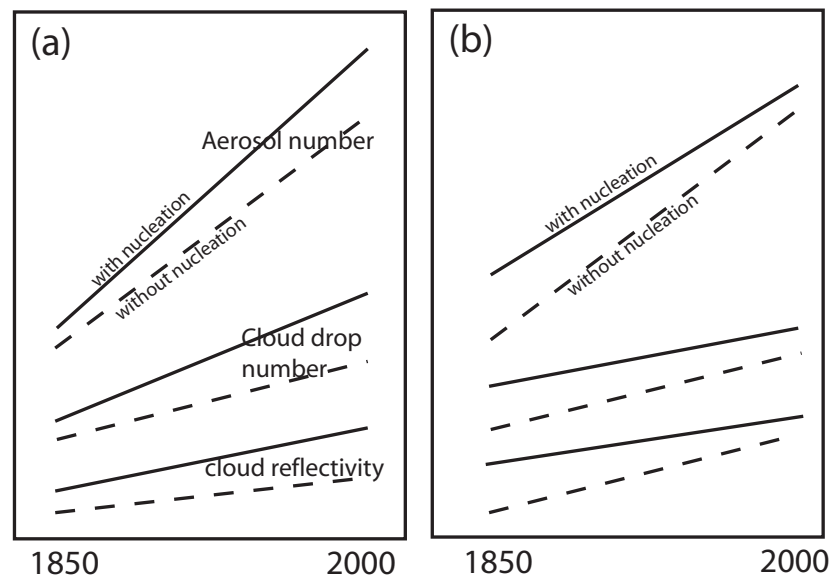

Fig. 3. Schematic showing how the inclusion of boundary layer nucleation can either increase or decrease the change in cloud albedo $(\Delta \mathrm{Rc}$ ) between 1850 and 2000. (a) Nucleation increases $\Delta \mathrm{Rc}$ : the fractional impact of nucleation on aerosol number, cloud drop number and cloud albedo is less in 1850 than in 2000. (b) Nucleation decreases $\Delta \mathrm{Rc}$ : the fractional impact of nucleation on aerosol number, cloud drop number and cloud albedo is greater in 1850 than in 2000. Note that fractional changes in CDNC are always smaller than fractional changes in aerosol number, and fractional changes in Rc are smaller still. So although the change in aerosol between 1850 and 2000 is much larger than any effect of activation-type BL particle formation, this is not the case for changes in albedo. The effect is exaggerated in the diagram.

portional effect in 1850 can be explained in two ways: that industrial emissions of precursor gases and primary aerosol in 2000 have acted to suppress BL particle formation, implying that increases in the condensation sink have outweighed increases in the nucleating $\mathrm{H}_{2} \mathrm{SO}_{4}$ vapour, or that a greater fraction of CDNC are due to primary particles in 2000.

\section{Conclusions and discussion}

We have used a global aerosol model to explore the effect of activation-type BL particle formation on global and regional CDNC. The obtained CDNC with particle formation are in good agreement with in-situ observations at marine and continental sites, while those without BL particle formation tend to underestimate CDNC. The effect on CDNC can be seen on most parts of the globe, but the relative contribution of particle formation to regional CDNC varies greatly. Furthermore, this contribution is nonlinear to in-situ particle formation rates. Particle formation can greatly enhance CDNC also in regions where in-situ formation rates are negligible due to long range transport of aerosol.

Our study suggests that BL particle formation could have significant consequences for the calculation of cloud albedo changes. Model simulations using emissions for 1850 and 
$\Delta R c$ with BLPF, full year

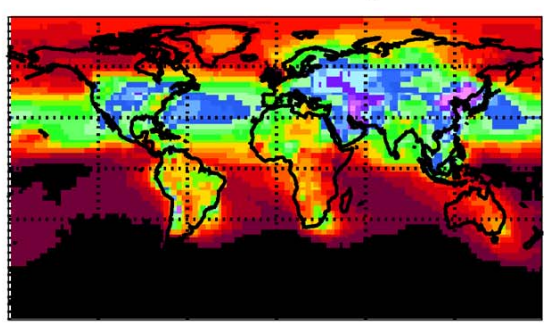

\begin{tabular}{llllll}
\hline & 7 & 15 & 22 & 30 & $\%$
\end{tabular}

$\Delta R c$ with BLPF, Summer

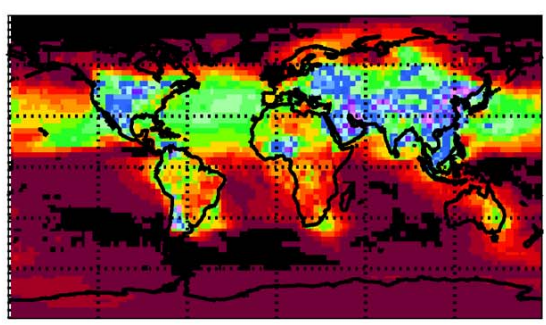

\begin{tabular}{llllll}
\hline 0 & 7 & 15 & 22 & 30 & $\%$
\end{tabular}
$\Delta R$ c without BLPF, full year

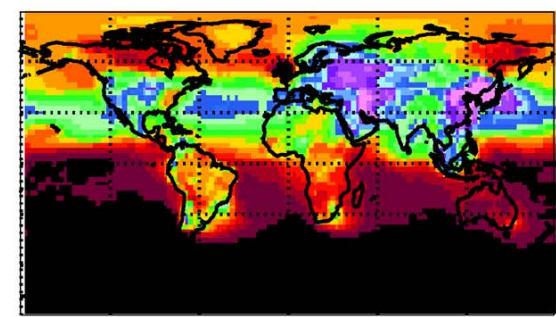

0

$\Delta R c$ without BLPF, Summer

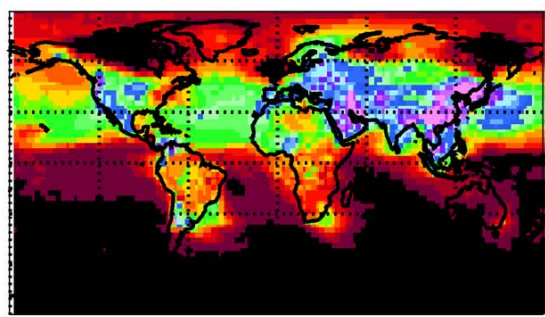

\begin{tabular}{lllll}
\hline 0 & 7 & 15 & 22 & 30
\end{tabular}

Fig. 4. The 1850-2000 change in cloud albedo with and without boundary layer particle formation at 300-1000 m above ground level. Results are shown for an initial albedo $\mathrm{Rc}=0.35$ assuming cloud updraft velocity $\bar{w}=0.4 \mathrm{~ms}^{-1}$.

2000 show that particle formation made a nearly equal contribution (16\%-13.5\%) to global CDNC in both years. However, there are distinct regional differences in the historical contribution of BL particle formation to CDNC that can affect albedo changes by more than $50 \%$. We find that there is a strong north-south contrast in the obtained albedo changes due to BL particle formation. With some exceptions, BL particle formation decreases the albedo changes in the polluted regions of northern hemisphere and increases the albedo changes in the southern hemisphere. In the Arctic BL particle formation appears to suppress the 1850 to 2000 summertime albedo change by as much as $43 \%$. Thus, BL particle formation was a much more important source of CDNC in the Arctic in 1850 than today. The explanation is that the sulfur pollution in the modern-day Arctic exists as sulfate aerosol, which act as a sink for new particles, rather than $\mathrm{SO}_{2}$, which would act as a source for particle formation.

Of importance for the pattern of radiative forcing is that BL particle formation enhances the long term increase in CDNC in the persistent stratocumulus regions to the west of Africa and west of South America. Without BL particle formation, the CDNC change west of South America is predicted to be $18.7 \%$ but with BL particle formation it is $29.0 \%$. This leads to an estimated $49 \%$ enhancement in the 1850-2000 change in cloud albedo. New observations combined with high resolution cloud-scale modelling of outflow of pollutants from South America are needed to improve our low resolution model estimate. In the persistent stratocumulus region East of North-East Asia the 1850-2000 albedo enhancement is particularly strong. With BL particle formation, the obtained albedo enhancement is reduced by $18.4 \%$.

The impact on climate change needs to be considered in longer simulations that include a calculation of cloud radiative forcing and the co-location of cloud type and CDNC change. Substantial changes in cloud albedo are predicted in regions with persistent low level clouds, but there are also substantial effects on CDNC in regions where other cloud types dominate. The substantial suppression of summertime Arctic indirect effect needs further investigation. Our model captures Arctic summertime particle size distributions fairly well (Korhonen et al., 2008) but, given the importance of Arctic climate change, further work is needed in this area. We also find that the effect of BL particle formation on CDNC becomes more pronounced at higher updraft velocities since smaller particles become activated. Climate model simulations of the effects of CDNC on high updraft cumulus clouds are at an early stage (Wu et al., 2007), but nucleation could have an important influence on long term changes in CDNC in these clouds.

Recent studies by Wang and Penner (2009) and Pierce and Adams (2009) have showed that historical change in the impact of BL particle formation on clouds depends on the selected representation of primary particle emissions. There are uncertainties in the emitted total mass and size 


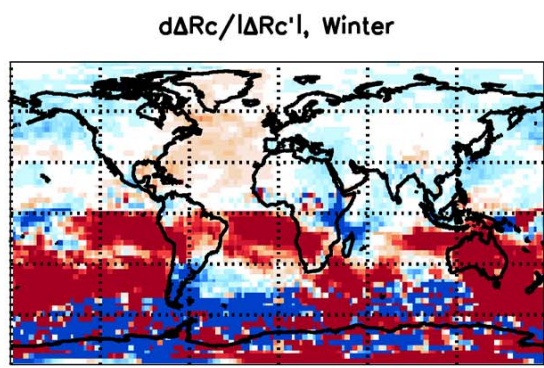

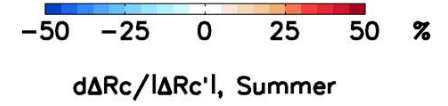
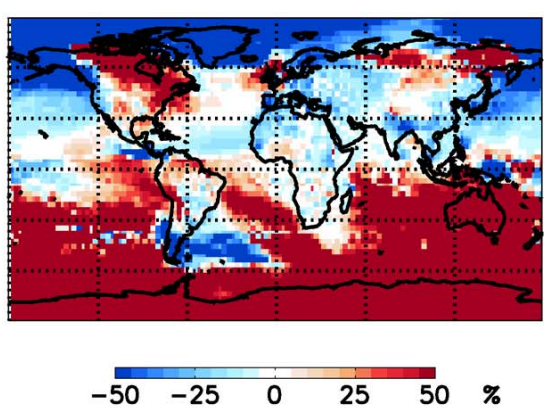

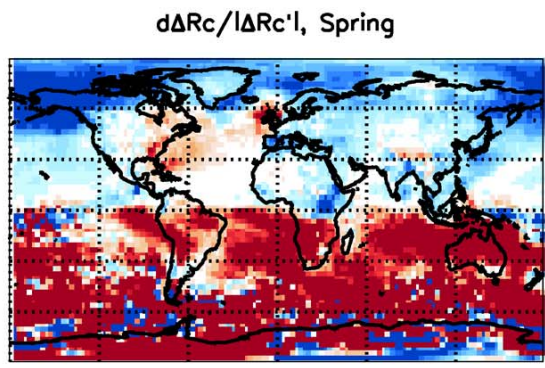

$d \Delta R c / \mid \Delta R c^{\prime} l$, Spring
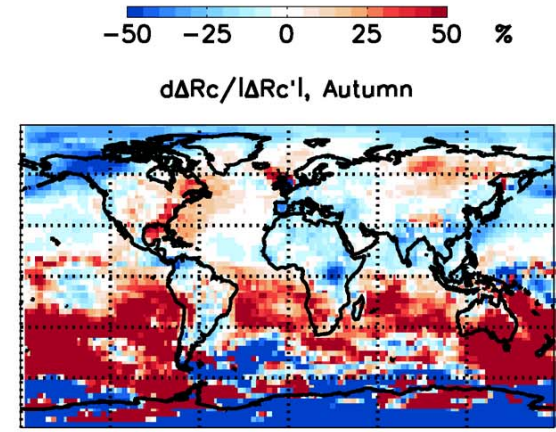

$\begin{array}{llllll}-50 & -25 & 0 & 25 & 50 & \%\end{array}$

Fig. 5. Upper panel: The relative error in calculation of the change in cloud albedo if activation BL particle formation is neglected at $300-1000 \mathrm{~m}$ above ground level. Results are shown for four northern hemisphere seasons. The updraft velocity is taken to be $\bar{w}=0.4 \mathrm{~m} / \mathrm{s}$.

distribution of primary particles both in 1850 and 2000 . Wildfires represent a major but uncertain component in 1850 continental primary emissions. Recent charcoal records suggest that global wildfire activity was much higher in 1850 than today (Marlon et al., 2008). For 1850 we have used a population-weighted average of AEROCOM estimates for years 1750 and 2000 (Dentener et al., 2006) where wildfire emissions in the high latitudes in the northern hemisphere (Europe, N. America, Russia) are higher in 1850 than in 2000 due to less fire suppression, but total emissions are lower in 1850 than in 2000 due to changes in population and land use. We show that the regional contribution of BL particle formation to CDNC is not the same over the period 1850 to 2000. Therefore, climate model studies that do not account for BL particle formation are likely to get the regional climate forcing from anthropogenic aerosol incorrect. Both this work and that of Pierce and Adams (2009) show that on a global scale BL particle formation contributes equally, to CDNC and CCN concentrations respectively, over this period. There are significant uncertainties in the emissions of primary particles and aerosol precursor gases. With different emission assumptions historical changes in BL particle formation may also be important at the global scale.

There are also uncertainties in the BL particle formation rate that can affect the results. In this study we have assumed a universally constant activation nucleation rate coefficient $A=2 \times 10^{-6} \mathrm{~s}^{-1}$, but observed rate coefficients vary between $10^{-8}-10^{-4} \mathrm{~s}^{-1}$ for different nucleation events (Riipinen et al., 2007). It is not clear if a single rate coefficient can be applied in different regions. We also assume the same rate coefficient for 1850 to 2000 , but it is possible that some unknown factors contributing to the rate coefficient have changed since 1850 . However, our other work (Spracklen et al., 2008; Merikanto et al., 2009) has shown that $\mathrm{CCN}$ (and therefore $\mathrm{CDN}$ ) are fairly insensitive to large changes in the A-factor. The fundamental mechanism of particle formation is still poorly understood, and the process may be limited by the abundance of some other chemical species beside sulfuric acid as assumed here. For example, it has been suggested that the neutral activated cluster may constitute ammonia and sulfuric acid (Vehkamaki et al., 2004; Ortega et al., 2008), which may affect the nucleation rate in some regions (Gaydos et al., 2005; Jung et al., 2006). It is also possible that biogenic organic species control BL particle formation (Bonn et al., 2008).

It may take time before the fundamental mechanism, or mechanisms, of atmospheric particle formation are resolved. However, since its contribution to CDNC and total particle concentrations appears to be large, best available representations should be utilized when estimating of the effects of aerosols on climate. 
Acknowledgements. This work was supported by grants from NERC: (AEROFORM NE/D01395X/1 and APPRAISE CP3), a Royal Society International Joint Project, and the EU EUCAARI integrated project. J. Merikanto was also supported by Academy of Finland grant no. 126105.

Edited by: A. Wiedensohler

\section{References}

Adams, P. J. and Seinfeld, J. H.: Predicting global aerosol size distributions in general circulation models, J. Geophys. Res., 107(D19), 4370, doi:10.1029/2001JD001010, 2002.

Bond, T., Bhardwaj, E., Dong, R., Jogani, R., Jung, S., Roden, C., Streets, D. G., and Trautmann, N. M.: Historical emissions of black and organic carbon aerosol from energy-related combustion, 1850-2000, Global Biogeochem. Cycles, 21, GB2018, doi:10.1029/2006GB002840, 2007.

Bonn, B., Kulmala, M., Riipinen, I., Sihto, S.-L., and Ruuskanen, T. M.: How biogenic terpenes govern the correlation between sulfuric acid concentrations and new particle formation, J. Geophys. Res., 113, D12209, doi:10.1029/2007JD009327, 2008.

Chipperfield, M.: New version of the TOMCAT/SLIMCAT offline chemical transport model: Intercomparison of stratospheric tracer experiments, Q. J. R. Meteorol. Soc., 132, 1179-1203, doi:10.1256/qj.05.51, 2006.

Dentener, F., Kinne, S., Bond, T., Boucher, O., Cofala, J., Generoso, S., Ginoux, P., Gong, S., Hoelzemann, J. J., Ito, A., Marelli, L., Penner, J. E., Putaud, J.-P., Textor, C., Schulz, M., van der Werf, G. R., and Wilson, J.: Emissions of primary aerosol and precursor gases in the years 2000 and 1750 prescribed data-sets for AeroCom, Atmos. Chem. Phys., 6, 4321-4344, 2006,

http://www.atmos-chem-phys.net/6/4321/2006/.

Dusek, U., Frank, G. P., Hildebrandt, L., Curtius, J., Schneider, J., Walter, S., Chand, D., Drewnick, F., Hings, S., Jung, D., Borrmann, S., and Andreae, M. O.: Size Matters More Than Chemistry for Cloud-Nucleating Ability of Aerosol Particles, Science, 312, 1375, doi:10.1126/science.1125261, 2006.

Fernandes, S. D., Trautmann, N. M., Streets, D. G., Roden C. A., and Bond, T., C.: Global biofuel use, 1850-2000, Global Biogeochem. Cy., 21, GB2019, doi:10.1029/2006GB002836, 2007.

Fountoukis, C. and Nenes, A.: Continued developement of a cloud droplet formation parameterization for global climate models, J. Geophys. Res.-Atmos., 110, D11212, doi:10.1029/2004JD005591, 2005.

Fountoukis, C., Nenes, A., Meskhidze, N., Bahreini, R., Conant, W. C., Jonsson, H. Murphy, S., Sorooshian, A., Varutbangkul, V., Brechtel, F., Flagan, R. C., and Seinfeld J. H.: Aerosolcloud drop concentration closure for clouds sampled during the International Consortium for Atmospheric Research on Transport and Transformation 2004 campaign, J. Geophys. Res., 112, D10S30, doi:10.1029/2006JD007272, 2007.

Gaydos, T. M., Stanier, C. O., and Pandis, S. N.: Modeling of in situ ultrafine atmospheric particle formation in the eastern United States, J. Geophys. Res., 110, D07S12, doi:10.1029/2004JD004683, 2005.

Gong, S. L.: A parameterization of sea-salt aerosol source function for sub- and super-micron particles, Global Biogeochem. Cy., 17(4), 1097,doi:10.1029/2003GB002079, 2003.
Guenther, A., Hewitt, C. N., Erickson D., et al.: A global model of natural volatile organic compound emissions, J. Geophys. Res., 100, 8873-8892, 1995.

Gultepe, I. and Isaac, G. A.: The effects of air-mass origin on Arctic cloud microphysical parameters during FIRE. ACE, J. Geophys. Res., 107(C10), 8029, doi:10.1029/2000JC000440, 2002

Gultepe, I. and Isaac, G. A.: Aircraft observations of cloud droplet number concentration: Implications for climate studies, Q. J. Roy. Meteorol. Soc., 130, 2377-2390, doi:10.1256/qj.03.120, 2004.

Hirsikko, A., Laakso, L., Horrak, U., Aalto, P.P., Kerminen, V.M., and Kulmala, M.: Annual and size dependent variation of growth rates and ion concentrations in boreal forest, Boreal Environ. Res., 10(5), 357-369, 2005.

IPCC: 4th Assessment Report of the Intergovernmental Panel on Climate Change, IPCC, Geneva, Switzerland, WG1, 502, 2007.

Jung, J, Adams, P. J., and Pandis, S. N.: Simulating the size distribution and chemical composition of ultrafine particles during nucleation events, Atmos. Environ., 40, 2248-2259, 2006.

Kerminen, V.-M. and Kulmala, M.: Analytical formulae connecting the "real" and the apparent nucleation rate and the nuclei number concentration for atmospheric nucleation events, J. Aerosol Sci., 33, 609-622, 2002.

Kerminen, V.-M., Lihavainen, H., Komppula, M., Viisanen, Y., and Kulmala, M.: Direct observational evidence linking atmospheric aerosol formation and cloud droplet activation, Geophys. Res. Lett., 32, L14803, doi:10.1029/2005GL023130, 2005.

Korhonen, H., Carslaw, K. S., Spracklen, D. V., Ridley, D. A., and Ström, J.: A global model study of processes controlling aerosol size distribution in the Arctic spring and summer, J. Geophys. Res., 113, D08211, doi:10.1029/2007JD009114, 2008.

Kuang, C., McMurry, P. H., McCormick, A. V., and Eisele, F. L.: Dependence of nucleation rates on sulfuric acid vapor concentration in diverse atmospheric locations, J. Geophys. Res., 113, D10209, doi:10.1029/2007JD009253, 2008.

Kulmala, M., Laaksonen, A., and Pirjola, L.: Parameterizations for sulfuric acid/water nucleation rates, J. Geophys. Res.-Atmos., 103(D7), 8301-8307, 1998.

Kulmala, M., Vehkamäki, H., Petäjä, T., Dal Maso, M., Lauri, A., Kerminen, V.-M., Birmili, W., and McMurry, P. H.: Formation and growth of ultrafine atmospheric particles: a review of observations, J. Aerosol Sci., 35, 143-176, doi:10.1016/j.jaerosci.2003.10.003, 2004a.

Kulmala, M., Kerminen, V.-M., Anttila, T., Laaksonen, A., and O'Dowd, C. D.: Organic aerosol formation via sulphate cluster activation, J. Geophys. Res.-Atmos., 109(D4), D04205, doi:10.1029/2003JD003961, 2004b.

Kulmala, M., Lehtinen, K. E. J., and Laaksonen, A.: Cluster activation theory as an explanation of the linear dependence between formation rate of $3 \mathrm{~nm}$ particles and sulphuric acid concentration, Atmos. Chem. Phys., 6, 787-793, 2006, http://www.atmos-chem-phys.net/6/787/2006/.

Laaksonen, A., Hamed, A., Joutsensaari, J., Hiltunen, L., Cavalli, F., Junkermann, W., Asmi, A., Fuzzi, S., and Facchini, M. C.: Cloud condensation nucleus production from nucleation events at a highly polluted region, Geophys. Res. Lett., 32, L06812, doi:10.1029/2004GL022092, 2005.

Lihavainen, H., Kerminen, V.-M., Komppula, M., Hatakka, J., Aaltonen, V., Kulmala, M., and Viisanen, Y.: Production of "po- 
tential" cloud condensation nuclei associated with atmospheric new-particle formation in northern Finland, J. Geophys. Res., 108(D24), 4782, doi:10.1029/2003JD003887, 2005.

Lohmann, U. and Feichter, J.: Global indirect aerosol effects: a review, Atmos. Chem. Phys., 5, 715-737, 2005, http://www.atmos-chem-phys.net/5/715/2005/.

Makkonen, R., Asmi, A., Korhonen, H., Kokkola, H., Järvenoja, S., Räisänen, P., Lehtinen, K. E. J., Laaksonen, A., Kerminen, V.M., Järvinen, H., Lohmann, U., Bennartz, R., Feichter, J., and Kulmala, M.: Sensitivity of aerosol concentrations and cloud properties to nucleation and secondary organic distribution in ECHAM5-HAM global circulation model, Atmos. Chem. Phys., 9, 1747-1766, 2009, http://www.atmos-chem-phys.net/9/1747/2009/.

Marlon, J. R., Bartlein, P. J., Carcaillet, C., Gavin, D. G., Harrison, S. P., Higuera, P. E., Joos, F., Power, M. J., and Prentice, I. C.: Climate and human influences on global biomass burning over the past two millennia, Nature Geoscience 1, 697-701, 2008.

Merikanto, J., Napari, I., Vehkamäki, H., Anttila, T., and Kulmala, M.: New parameterization of ternary sulfuric acid-ammoniawater ternary nucleation rates at tropospheric conditions, J. Geophys. Res.-Atmos., 112, D15207, doi:10.1029/2006JD007977, 2007.

Merikanto, J., Spracklen, D. V., Mann, G. W., Pickering, S. J., and Carslaw, K. S.: Impact of nucleation on global CCN, Atmos. Chem. Phys., 9, 8601-8616, 2009,

http://www.atmos-chem-phys.net/9/8601/2009/.

Meskhidze, N., Nenes, A., Conant, W. C., and Seinfeld, J. H.: Evaluation of a new cloud droplet activation parameterization with in situ data from CRYSTAL-FACE and CSTRIPE, J. Geophys. Res., 110, D16202, doi:10.1029/2004JD005703, 2005.

Nenes, A. and Seinfeld, J. H.: Parameterization of cloud droplet formation in global climate models, J. Geophys. Res.-Atmos., 108(D14), 4415, doi:10.1029/2002JD002911, 2003.

Nenes., A., Ghan, S., Abdul-Razzak, H., Chuang, P. Y., and Seinfeld, J. H.: Kinetic Limitations on Cloud Droplet Formation and Impact on Cloud Albedo, Tellus, 53B, 133-149, 2001.

O’Dowd, C. D., Aalto, P., Hämeri, K., Kulmala, M., and Hoffmann, T.: Atmospheric particles from organic Vapours, Nature, 416, 497-498, 2002a.

Ortega, I. K., Kurtén, T., Vehkamäki, H., and Kulmala, M.: The role of ammonia in sulfuric acid ion induced nucleation, Atmos. Chem. Phys., 8, 2859-2867, 2008,

http://www.atmos-chem-phys.net/8/2859/2008/.

Penner, J. E., Quaas, J., Storelvmo, T., Takemura, T., Boucher, O., Guo, H., Kirkevåg, A., Kristjánsson, J. E., and Seland, Ø.: Model intercomparison of indirect aerosol effects, Atmos. Chem. Phys., 6, 3391-3405, 2006,

http://www.atmos-chem-phys.net/6/3391/2006/.

Pierce, J. R. and Adams, P. J.: Uncertainty in global CCN concentrations from uncertain aerosol nucleation and primary emission rates, Atmos. Chem. Phys., 9, 1339-1356, 2009, http://www.atmos-chem-phys.net/9/1339/2009/.

Pringle, K. J., Carslaw, K. S., Spracklen, D. V., Mann, G. M., and Chipperfield, M. P.: The relationship between aerosol and cloud drop number concentrations in a global aerosol microphysics model, Atmos. Chem. Phys., 9, 4131-4144, 2009,

http://www.atmos-chem-phys.net/9/4131/2009/.

Riipinen, I., Sihto, S.-L., Kulmala, M., Arnold, F., Dal Maso, M.,
Birmili, W., Saarnio, K., Teinilä, K., Kerminen, V.-M., Laaksonen, A., and Lehtinen, K. E. J.: Connections between atmospheric sulphuric acid and new particle formation during QUEST III/IV campaigns in Heidelberg and Hyytiälä, Atmos. Chem. Phys., 7, 1899-1914, 2007,

http://www.atmos-chem-phys.net/7/1899/2007/.

Schröder F. P., Kärcher, B., Fiebig, M., and Petzold, A.: Aerosol states in the free troposphere at northern midlatitudes, J. Geophys. Res., 107(D21), 8126, doi:10.1029/2000JD000194, 2002.

Smith, S. J., Andres, R., Conception, E., and Lurz, J.: Historical sulfur dioxide emissions 1850-2000: Methods and results, PNNL Research Report, PNNL-14537, 2004.

Sihto, S.-L., Kulmala, M., Kerminen, V.-M., Dal Maso, M., Petäjä, T., Riipinen, I., Korhonen, H., Arnold, F., Janson, R., Boy, M., Laaksonen, A., and Lehtinen, K. E. J.: Atmospheric sulphuric acid and aerosol formation: implications from atmospheric measurements for nucleation and early growth mechanisms, Atmos. Chem. Phys., 6, 4079-4091, 2006,

http://www.atmos-chem-phys.net/6/4079/2006/.

Spracklen, D. V., Pringle, K. J., Carslaw, K. S., Chipperfield, M. P., and Mann, G. W.: A global off-line model of size-resolved aerosol microphysics: I. Model development and prediction of aerosol properties, Atmos. Chem. Phys., 5, 2227-2252, 2005a, http://www.atmos-chem-phys.net/5/2227/2005/.

Spracklen, D. V., Pringle, K. J., Carslaw, K. S., Chipperfield, M. P., and Mann, G. W.: A global off-line model of size-resolved aerosol microphysics: II. Identification of key uncertainties, Atmos. Chem. Phys., 5, 3233-3250, 2005b,

http://www.atmos-chem-phys.net/5/3233/2005/.

Spracklen, D. V., Carslaw, K. S., Kulmala, M., Kerminen, V.-M., Mann, G. W., and Sihto, S.-L.: The contribution of boundary layer nucleation events to total particle concentrations on regional and global scales, Atmos. Chem. Phys., 6, 5631-5648, 2006, http://www.atmos-chem-phys.net/6/5631/2006/.

Spracklen, D. V., Carslaw, K.S., Kulmala, M., Kerminen, V.-M., Sihto, S.-L., Riipinen, I., Merikanto, J., Mann, G. W., Chipperfield, M. P., Wiedensohler, A., Birmili, W., and Lihavainen, H.: Contribution of particle formation to global condensation nuclei concentrations, Geophys. Res. Lett., 35, L06808, doi:10.1029/2007GL033038, 2008.

Twomey, S.: Aerosols, clouds and radiation, Atmos. Environ., Part A, 25, 2435-2442, 1991.

Vehkamäki, H., Napari, I., Kulmala, M., and Noppel, M.: Stable ammonium bisulphate clusters in the atmosphere, Phys. Rev. Let., 93, 148501, doi:10.1103/PhysRevLett.93.14850, 2004.

Wang, M. and Penner, J. E.: Aerosol indirect forcing in a global model with particle nucleation, Atmos. Chem. Phys., 9, 239-260, 2009, http://www.atmos-chem-phys.net/9/239/2009/.

Weber, R. J., McMurry, P. H., Eisele, F. L., and Tanner, D. J.: Measurements of expected nucleation precursor species and 3$500 \mathrm{~nm}$ diameter particles at Mauna Loa observatory, Hawaii, J. Atmos. Sci., 52, 2242-2257, 1995.

Weber, R. J., McMurry, P. H., Eisele, F. L., Tanner, D. J., and Jefferson, A.: Measurements of new particle formation and ultrafine particle growth rates at a clean continental site, J. Geophys. Res., 102, 4375-4385, 1997.

Wu, J., Zhang, M., and Lin, W.: A case study of a frontal system simulated by a climate model: Clouds and radiation, J. Geophys. Res., 112, D12201, doi:10.1029/2006JD008238, 2007. 